\title{
PENYULUHAN DEMAM BERDARAH DENGUE (DBD) KEPADA PELAJAR-PELAJAR DI PERGURUAN KRISTEN METHODIST-2 RANTAUPRAPAT
}

\author{
Saharnauli Janna Verawaty Simorangkir ${ }^{1}$ \\ Fakultas Kedokteran Universitas HKBP Nommensen Medan
}

\begin{abstract}
Abstrak
Penyakit DBD merupakan salah satu masalah kesehatan di Kota Medan. Pendekatan pemberantasan DBD yang berwawasan kepedulian masyarakat merupakan salah satu alternatif dalam rangka pengendalian penyebaran penyakit ini. Tujuan dari kegiatan ini adalah untuk memberikan penjelasan kepada pelajar-pelajar yang diharapkan dapat menjadi agent of change di lingkungannya dalam pemberantasan penyakit DBD. Metode kegiatan ini adalah penyuluhan. Kegiatan ini dinilai cukup berhasil, dimana peserta antusias untuk bertanya dan feedback dari peserta penyuluhan ini dinilai menarik dan bermanfaat. Kesimpulannya melalui keilmuan yang dimiliki dapat digunakan untuk memberikan pemahaman mengenai penyakit-penyakit kepada masyarakat, dan mendorong partisipasi masyarakat dalam pencegahan pertambahan kasus DBD di lingkungannya.
\end{abstract}

Kata Kunci : DBD, Pencegahan, Pemberantasan, Penyuluhan, Pelajar

\section{Abstract}

DHF disease is one of the health problems in Medan City. The approach to eradicating DHF with a public concern is one of the alternatives in order to control the spread of this disease. The purpose of this activity is to provide explanations to students who are expected to become agents of change in their environment in eradicating dengue. The method of this activity was counseling. This activity was considered quite successful, where the participants were enthusiastic about asking questions and the feedback from the participants was considered interesting and useful. In conclusion, through the knowledge that is owned, it can be used to provide an understanding of diseases to the community, and encourage community participation in preventing additional cases of DHF in their environment.

Key Words : DHF, Prevention, Eradication, Counseling

Correspondence author: Saharnauli Janna Verawaty Simorangkir, saharnauli@uhn.ac.id, Medan, Indonesia

\section{PENDAHULUAN}

\section{Latar Belakang Masalah}

Penyakit DBD telah menjadi salah satu penyakit yang mematikan sejak tahun 2013. Penyakit ini telah tersebar di 34 provinsi di Indonesia dengan jumlah kasus pada tahun 2019 sebanyak 137.761 kasus dengan Incidence rate per 100.000 penduduk sebesar 51,4\%, kasus yang meninggal adalah sebanyak 917 kasus, dan data CFR sebesar 0,7\%. Menurut data Profil Kesehatan Indonesia tahun 2019, 
provinsi Sumatera Utara menempati urutan ke 3 kasus DBD terbanyak setelah provinsi Jawa Barat dan Jawa Timur, dengan jumlah kasus sebanyak 7.731 kasus. Kasus ini menyebar hampir di seluruh kabupaten atau kota (96,97\%). ${ }^{1}$

Kelembaban yang tinggi dengan suhu berkisar antara $28-32^{\circ} \mathrm{C}$ membantu nyamuk Aedes bertahan hidup untuk jangka waktu yang lama. Pola penyakit di Indonesia sangat berbeda antara satu wilayah dengan wilayah lainnya. Tingginya angka kejadian DBD juga dapat dipengaruhi oleh kepadatan penduduk. Peningkatan jumlah kasus DBD dapat terjadi bila kepadatan penduduk meningkat. Semakin banyak manusia maka peluang tergigit oleh nyamuk Aedes aegypti juga akan lebih tinggi. ${ }^{2}$

Penyakit demam berdarah merupakan salah satu masalah kesehatan di Kota Medan yang cenderung menimbulkan kekhawatiran masyarakat karena perjalanan penyakitnya cepat dan dapat menyebabkan kematian dalam waktu yang singkat serta dapat menimbulkan kejadian luar biasa (KLB) atau wabah. Seluruh kecamatan di Kota Medan merupakan daerah endemis DBD, dimana setiap tahunnya terdapat kasus DBD. ${ }^{3}$ Upaya pemberantasan demam berdarah dapat dibagi dalam 3 kegiatan yaitu 1)Peningkatan kegiatan surveilans penyakit dan surveilans vektor, 2) Diagnosis dini dan pengobatan dini dan, 3) Peningkatan upaya pemberantasan vektor penular penyakit DBD. Upaya pemberantasan DBD dititikberatkan pada penggerakan potensi masyarakat untuk dapat berperan serta dalam pemberantasan sarang nyamuk (PSN) melalui 3 M plus (menguras, menutup dan mengubur plus, menabur larvasida), penyebaran ikan pada tempat penampungan air, penggerakan juru pemantau jentik (jumantik) serta pengenalan gejala DBD dan penanganannya di rumah tangga. Pendekatan pemberantasan DBD yang berwawasan kepedulian masyarakat merupakan salah satu alternatif pendekatan baru. ${ }^{4}$

Upaya Penanggulangan Penyakit DBD yang telah dilakukan di Kota Medan antara lain : 1) Penyuluhan/ Resosialisasi penyakit Demam Berdarah Dengue kepada masyarakat, sekolah dan masyarakat umum. 2) Pemberantasan 
Sarang Nyamuk (PSN) dengan gerakan 3M + 1T. 3) Pemeriksaan Jentik Berkala (PJB). 4) Melaksanakan Surveilans Epidemiologi 5) Abatisasi Selektif 6) Penyelidikan Epidemiologi di lokasi sumber penularan sampai Foging Fokus. 7) Melakukan koordinasi dengan Lintas Sektor 8) Melakukan Pertemuan Berkala dengan Kepala Puskesmas Dan Puskesmas Pembantu. 9) Advokasi ke pemangku kepentingan. ${ }^{3}$

Dalam rangka upaya membantu program pemerintah dalam penanggulan penyakit DBD, maka kami ingin melaksanakan penyuluhan mengenai demam berdarah dan tindakan pencegahannya kepada pelajar-pelajar yang diharapkan dapat menjadi agent of change dimulai dari dalam lingkungan keluarganya masing-masing.

\section{METODE PELAKSANAAN}

Penyuluhan dilakukan kepada pelajar-pelajar kelas VIII di Perguruan Kristen Methodist-2 Rantauprapat secara daring melalui aplikasi zoom cloud meetings. Kegiatan promosi kesehatan kepada masyarakat ini akan dilaksanakan dalam bentuk penyuluhan berupa tampilan media presentasi mengenai infeksi DBD dan tindakan pencegahannya. Kemudian akan diikuti dengan sesi tanya-jawab oleh peserta dan diikuti dengan aktivitas games. Feedback dari peserta akan diperoleh dari google form yang wajib diisi oleh seluruh peserta.

\section{HASIL DAN PEMBAHASAN}

Kegiatan pengabdian masyarakat ini melibatkan siswa siswi SMP Perguruan Kristen Methodist-2 yaitu sebanyak 28 orang dengan karakteristik yang dapat dilihat pada tabel 1. Sebagian besar peserta penyuluhan adalah perempuan (71,4\%) dan dari segi usia paling banyak peserta berusia 13 tahun (39,3\%).

Tabel 1. Karakteristik Peserta Penyuluhan

\begin{tabular}{|c|l|c|c|}
\hline \multicolumn{2}{|c|}{ Karakteristik } & Jumlah & Persentase \\
\hline \multirow{2}{*}{ Jenis Kelamin } & Laki-laki & 8 & $28,6 \%$ \\
\cline { 2 - 4 } & Perempuan & 20 & $71,4 \%$ \\
\hline
\end{tabular}




\begin{tabular}{|c|c|c|c|}
\hline \multirow{3}{*}{ Usia } & 12 & 10 & $35,7 \%$ \\
& 13 & 11 & $39,3 \%$ \\
& 14 & 4 & $14,3 \%$ \\
15 & 3 & $10,7 \%$ \\
\hline
\end{tabular}

Teknis pelaksanaan pengabdian masyarakat ini terdiri dari pembukaan oleh MC, penyuluhan dan sesi tanya jawab, games dan terakhir setiap peserta diwajibkan untuk mengisi feedback melalui google form. Peserta penyuluhan sangat antusias dan tertarik dengan penyuluhan ini, hal ini terlihat dari feedback yang diberikan peserta penyuluhan melalui google form (Tabel 2). Sebagian besar peserta penyuluhan berpendapat penyuluhan ini berjalan dengan sangat baik (50\%), dan seluruh peserta setuju bahwa penyuluhan ini sangat bermanfaat bagi mereka.

Tabel 2. Feedback pelaksanaan pengabdian

\begin{tabular}{|l|l|l|}
\hline \multicolumn{1}{|c|}{ Pertanyaan } & \multicolumn{1}{|c|}{ Jumlah } & \multicolumn{1}{|c|}{ Persentase } \\
\hline Jalannya penyuluhan & $\begin{array}{l}\text { Cukup } \\
\text { Biasa aja } \\
\text { Baik } \\
\text { Sangat baik }\end{array}$ & $\begin{array}{l}0 \\
42,9 \% \\
50 \%\end{array}$ \\
\hline $\begin{array}{l}\text { Apakah penyuluhan } \\
\text { ini bermanfaat }\end{array}$ & Ya \\
Tidak & $100 \%$ \\
$\begin{array}{l}\text { Apakah berminat } \\
\text { untuk mengikuti } \\
\text { kegiatan yang sama di } \\
\text { masa mendatang }\end{array}$ & $\begin{array}{l}\text { Ya } \\
\text { Belum tahu }\end{array}$ & $67,9 \%$ \\
Tidak & 0 \\
\hline
\end{tabular}

Pelaksanaan kegiatan pengabdian masyarakata ini meliputi penyuluhan dan tanya jawab berupa games di akhir acara untuk memperoleh feedback mengenai pemahaman peserta penyuluhan mengenai infeksi DBD dan tindakan-tindakan pencegahannya. Adapun poin-poin yang disampaikan pada saat penyuluhan antara lain definisi demam berdarah, vector penyebab demam berdarah, tanda dan gejala demam berdarah termasuk tanda-tanda darurat yang mengharuskan pasien segera 
dibawa ke rumah sakit, tatalaksana awal pada saat pasien masih di rumah dan tindakan-tindakan pencegahan yang dapat dilakukan untuk menurunkan angka kejadian DBD. Penyuluhan ini disampaikan oleh dosen yang juga berprofesi sebagai seorang dokter umum, dengan demikin sudah cukup berpengalaman untuk menyampaikan materi mengenai kesehatan dan pengobatan DBD yang sesuai.

Peserta penyuluhan sangat antusias dengan topik yang disampaikan, terbukti dari banyaknya pertanyaan yang diajukan selama sesi tanya jawab. Pertanyaaan-pertanyaan yang muncul selama sesi tanya-jawab antara lain : apakah virus dengue penyebab DBD ini hanya dapat berkembang di dalam tubuh nyamuk? Transmisi virus dengue dikenal dengan dua tipe transimisi yaitu transmisi horizontal dan vertikal. Dan transmisi ini hanya dapat terjadi pada tubuh nyamuk Aedes aegypti dan aedes albopyctus betina. Transmisi horizontal terjadi ketika nyamuk menggigit inang yang sudah terinfeksi, sedangkan transimi vertikal terjadi antara induk nyamuk dan keturunannya. ${ }^{8}$ Pertanyaan berikutnya dimanakah tempat favorit nyamuk Aedes aegypti berkembang. Tempat favorit nyamuk ini berkembang biak adalah di tempat yang beriklim panas dan lembab, baik itu di dalam maupun di sekitar rumah. Nyamuk ini berkembang biak di tempat-tempat penampungan air seperti toilet, pot tanaman, ban bekas, tempat minum hewan, kolam renang. Juga di tempat-tempat gelap dan lembab seperti lemari pakaian, bagian bawah tempat tidur dan sisi belakang lemari. ${ }^{9}$

Pertanyaan lainnya yaitu mengenai vaksin DBD, berapa kali harus diberikan dan apakah memang benar bisa mencegah seseorang terkena DBD. Vaksin DBD merupakan salah satu upaya efektif untuk menurunkan angka kejadian DBD. Vaksin DBD telah mulai dikembangkan sejak tahun 1970-an sampai saat ini, dan diharapkan dapat efektif melindungi dari keempat serotipe virus dengue. Vaksin DBD dapat diberikan sejak usia 9 tahun, akan tetapi keefektifannya masih diragukan dan harganya juga masih relative mahal. ${ }^{10}$ Dan pertanyaan lanjutannya apakah bila sistem imun baik dapat mencegah seseorang terkena DBD. Sistem imun tubuh yang 
kuat dapat mencegah tubuh kita terinfeksi berbagai jenis mikroba penyebab penyakit. Oleh karena itu selain dengan mengontrol kebersihan lingkungan, cara lain yang juga efektif dalam mencegah terjadinya DBD adalah meningkatkan sistem imun. ${ }^{11}$

Peserta penyuluhan juga menanyakan bagaimana cara kita mengenali bahwa seseorang telah terinfeksi virus dengue. Tanda dan gejala demam dengue akan muncul sekitar 3-15 hari setelah digigit nyamuk aedes yang telah terinfeksi. Gejala yang muncul dapat demam, nyeri pada seluruh otot dan tulang, nyeri di belakang mata, mual muntah,ruam pada kulit, tanda-tanda kebocoran plasma seperti nyeri perut yang hebat, perdarahan dari hidung atau gusi, muntah darah, BAB berdarah, kulit pucat dan terasa dingin. Sedangkan pada hasil laboratorium pemeriksaan darah dapat ditemukan penurunan jumlah trombosit, hemoglobin dan hasil pemeriksaan antibody $\operatorname{IgG}$ dan IgM terhadap virus dengue. ${ }^{7}$

Beberapa peserta tertarik untuk bertanya mengenai pilihan tatalaksana dari demam berdarah, jenis cairan yang diberikan, apakah ada jenis makanan tertentu yang dapat menyembuhkan penyakit ini. Terapi utama untuk penyakit DBD adalah pemberian cairan. Pada pasien DBD tingkat 1 dan 2 yang tidak memiliki gejala syok ataupun tidak mengalami mual dan muntah, diberikan cairan secara oral. ${ }^{5}$ Cairan yang diberikan dapat berupa cairan isotonik, air putih, sup yang dapat dikonsumsi oleh pasien dalam jumlah cukup untuk menghindari terjadinya dehidrasi. Pemberian sup pada pasien DBD dapat membantu meningkatkan daya tahan tubuh tetapi bukan sebagai obat untuk virus DBD. Selain itu juga pasien perlu diberikan obat penuruan panas setiap 6 jam selama masih dirawat di rumah. Jangan memberikan jenis obat ibuprofen, aspirin. Selain itu juga bisa dibantu dengan pemberian kompres air hangat di tubuh pasien, untuk membantu menurunkan suhu tubuh. ${ }^{12}$ 
pp 33-41

ISSN : 2746-766X

https://ejournal.uhn.ac.id/index.php/pengabdian
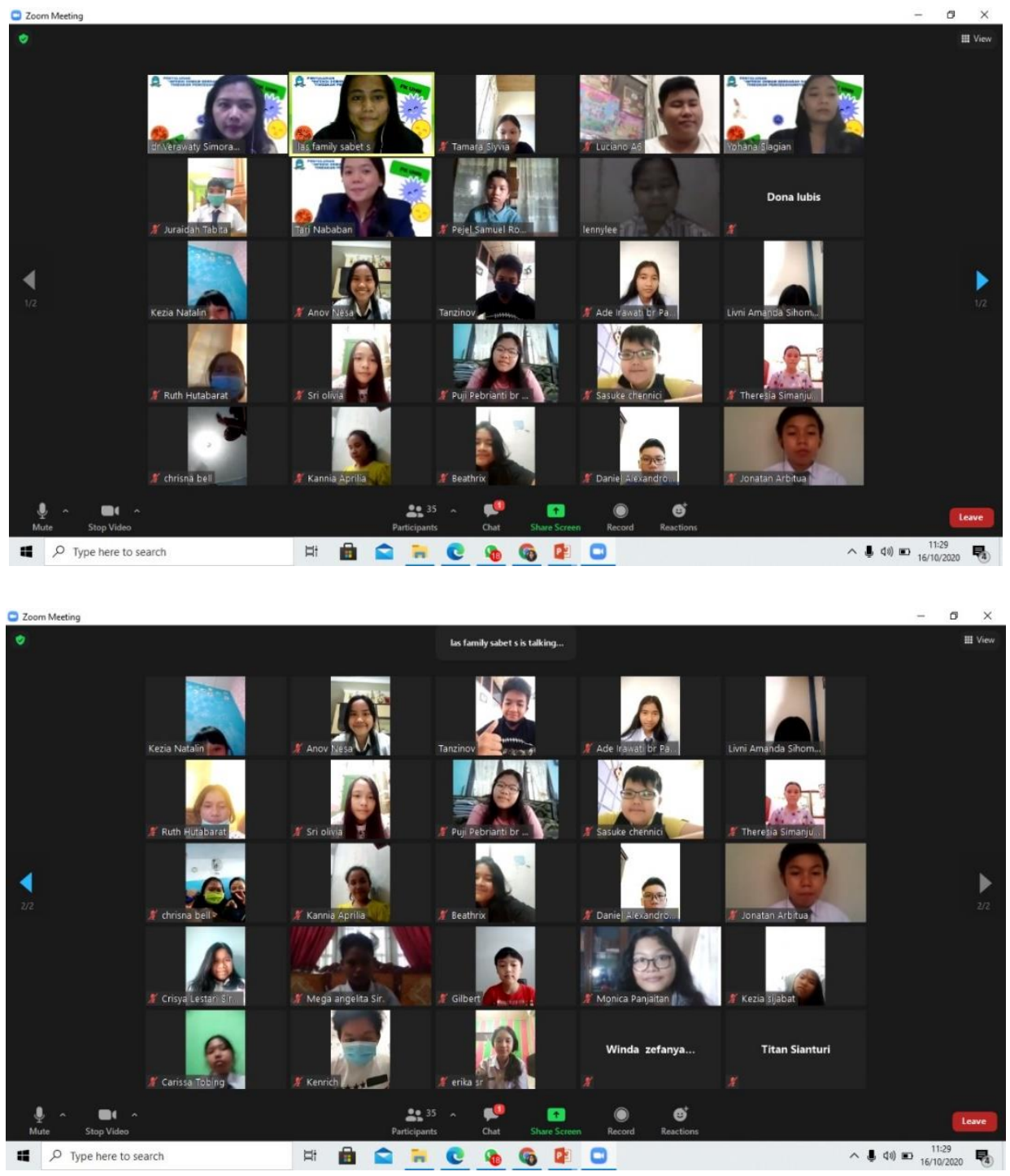

Gambar 1. Dokumentasi Pelaksanaan Kegiatan

\section{KESIMPULAN}

Berdasarkan kegiatan pengabdian masyarakat yang telah dilaksanakan secara daring ini, maka dapat diambil beberapa kesimpulan. Pertama, topik penyuluhan yang disampaikan sesuai dengan kebutuhan peserta penyuluhan, hal ini dapat dinilai dari hasil feedback bahwa penyuluhan ini dirasakan sangat bermanfaat oleh seluruh peserta. Kedua, melalui penyuluhan ini kami dapat mengajak anak-anak 
usia sekolah untuk turut serta menjaga lingkungannya dalam rangka mendukung kegiatan pencegahan demam berdarah. Selanjutnya, kami sebagai narasumber juga banyak belajar bagaimana keilmuan kami dapat membantu memberikan pemahaman mengenai penyakit-penyakit kepada masyarakat, yang pada akhirnya dapat mendorong partisipasi masyarakat dalam pencegahan penularan dan pertambahan kasus-kasus penyakit tertentu di masyarakat.

\section{DAFTAR PUSTAKA}

Pongsilurang CM, Sapulete MR, Kaunang. J WP., Pemetaan kasus demam berdarah dengue di Kota Manado, J Kedokt Komunitas dan Trop. 2015;3(2):66-72.

Cucunawangsih, Lugito NPH, Trends of dengue disease epidemiology, Virol Res Treat. $2017 ; 8: 1-6$.

Kasbe T, Pippal RS, Dengue Fever: State-of-the-Art Symptoms and Diagnosis, International Journal of Computer Sciences and Engineering Open Access Dengue Fever: State-of-the-Art Symptoms and Diagnosis. JCSE. 2020;4(6):26-30.

Ferreira-De-Lima VH, Lima-Camara TN, Natural vertical transmission of dengue virus in Aedes aegypti and Aedes albopictus: A systematic review, Parasites and Vectors. $2018 ; 11(1): 1-8$.

Rothman AL, Vector Dynamics and Transmission of Dengue Virus: Implications for Dengue Surveillance and Prevention Strategies, Curr Top Microbiol Immunol. 2010;338(1):116-24.

Marbawati D, Wijayanti T, Vaksin dengue, tantangan, perkembangan dan strategi, Balaba. 2014;10(01):39-46.

Katzelnick LC, Harris E, Immune correlates of protection for dengue: State of the art and research agenda, Vaccine. 2017;35(36):4659-69.

Lewandowski CM, Co-investigator N, Lewandowski CM, Dengue Case Management, Cdc. $2015 ; 1: 1-8$.

\section{Sumber Internet:}


Profil Kesehatan Indonesia Tahun 2019. Kementrian Kesehatan RI; 2019. p. 169-70. Profil Kesehatan Kota Medan Tahun 2018. Dinas Kesehatan Kota Medan; 2019.

Profil Kesehatan Sumut 2017. 2017. p. 69-70.

WHO. Comprehensive guidelines for prevention and control of dengue and dengue haemorrhagic fever, WHO Regional Publication SEARO. 2011. 159-168 p. Available from: http://scholar.google.com/ scholar?hl=en\&btnG=Search\&q=intitle: Comprehensive+Guidelines + for + Prevention + and + Control + of $+\quad$ Dengue + and + Dengue + Haemorrhagic + Fever\#1 